\title{
Centralization and government
}

\section{competition ${ }^{1}$}

\author{
DAVID JOULFAIAN* and MICHAEL L. MARLOW \\ * Office of Tax Analysis, US Department of Treasury, Washington, DC 20220, USA \\ ${ }^{\ddagger}$ Department of Economics, California Polytechnic State University, San Luis Obispo, \\ CA 93407, USA
}

This paper examines the relationship between government size and fiscal centralization with specific focus on the separate influences of centralism and fragmentation on the size of the public sector in the United States. The empirical findings at the national level provide support to the hypothesis that fiscal decentralization leads to a smaller government. The findings at the state and local levels, however, show no empirical relationship between government size and the degree of centralization.

\section{INTRODUCTION}

This paper addresses the issue of whether or not governments act as monopolists when competitors are weak or absent. At stake are issues regarding the behaviour of government officials and institutions and whether or not government should be modelled along the lines of traditional microtheory. One end of the debate argues that whenever intergovernmental competition is weak, governments act as self-interested monopolists that seek to expand their influence over the economy. Greater monopolization, or centralization, is argued to lead to larger, more inefficient government. Taxpayer-flight away from high-tax, inefficient political jurisdictions is seen to be more difficult the greater is the degree of government monopolization. ${ }^{2}$ The other end of the debate argues that, because production is subject to substantial economies of scale, more centralized government should be associated with smaller, more efficient government. While both sides may contain elements of truth, the net effect of centralization on government size suggests which of the views dominate the relationship between government size and fiscal structure.

This paper argues that the research methodologies of many previous studies of the centralization hypothesis are suspect because they have not examined all units of govern- ment. Examination of only state or county government levels is typical and addresses only the 'fragmentation' issue which measures the degree of competition between noncentral governments. However, there also exists the centralization' issue which poses the possibility that central governments influence intergovernmental competitive environments by affecting the ability of taxpayers to discipline governments through taxpayer-fiight. Holding total government size constant, this centralization issue suggests that, because a relatively large central government weakens the relative importance of non-central governments to taxpayers, the benefits to disciplining governments through taxpayer-mobility is inversely related to central government size. Exclusion of the central government removes one potentially important factor that describes the competitive environment of governments.

Many studies in fiscal federalism implicitly assume that the central government exerts no competitive influence on intergovernmental relationships. We argue that this assumption merits further investigation. ${ }^{3}$ State cross-sectional data on the activities of local, state and federal governments are examined in order to study whether the centralization hypothesis is sensitive to inclusion of the central government. Our conclusions suggest that the literature's assumption that central governments play an insignificant role in

\footnotetext{
${ }^{1}$ The views expressed in this paper are those of the authors and should not be attributed to the US Department of Treasury.

${ }^{2}$ Of course, it is possible that both greater monopolization and immobility might be correlated in practice, as far as both are dependent on the geographical size of government.

${ }^{3}$ Oates (1989) suggests further study of the centralization hypothesis along the lines of sorting out the differences between the fragmentation and centralization aspects of fiscal structure.
} 
intergovernmental competition is incorrect. We conclude that differences in support offered by fragmentation and decentralization measures of competition suggest that the degree of fragmentation, or the degree of competition between local and state governments, is not as important as the share of the central government in the economy.

\section{GOVERNMENTAL CENTRALIZATION LITERATURE}

That centralization promotes government expansion follows from the revenue-maximizing model of government in Brennan and Buchanan (1980). ${ }^{4}$ Discussions of the theoretical framework for this centralization hypothesis may be found in Brennan and Buchanan (1980), Oates (1985) and Wiseman (1990). Specific discussion of the possibility that central governments influence individual migration decisions at the state and local levels of government is contained in Grewal (1988). Briefly, the literature argues that intergovernmental competition may act as a constraining device on total government size because citizens are believed to vote-with-their-feet along the lines of the Tiebout (1956) model. It is hypothesized that, when governments are subject to little competition, political self-interests are promoted as evidenced by relatively costly production and high taxes. Therefore, this view hypothesizes that fiscal decentralization acts as a stimulus to intergovernmental competition, which in turn will restrain revenue-maximizing governments. This hypothesis is consistent with Niskanen's (1971) model regarding monopoly bureaus and a number of empirical studies (Ahlbrandt, 1973; DeAllesi, 1974; Boardman and Vining, 1989) that indicate that government production is less efficient than private production of the same activities. Also consistent is the literature which argues that governments act like monopolists when they attempt to limit entry into their markets. DiLorenzo (1981) finds that larger government is the result of entry restrictions on singlepurpose special districts. Similar evidence is reported in Wagner and Weber (1975) and Wagner and Martin (1978).

The counter-hypothesis argues that centralization leads to lower production costs because decentralized government leads to redundancy in production. Oates (1985) argues that, to the extent that decentralization reduces the ability of governments to exploit economies of scale, higher decentralization will result in larger government budgets. We argue that the potential relevancy of this issue must consider two factors. First, is government production subject to economies of scale? Second, even if scale economies exist, would the resulting higher government centralization result in Brennan and Buchanan's prediction of monopolistic behaviour on the part of governments? Therefore, potential tradeoffs between scale economies and greater centralization exist and it is not clear a priori which effects dominate the fiscal structure-government size relationship.

Previous empirical evidence on this hypothesis consists of many methodologies and levels of data aggregation. Giertz (1981) finds a positive relation between tax revenue centralization (ratio of state-to-state and local tax collections) and state and local government expenditures. DiLorenzo (1983) finds that greater interjurisdictional competition within large cities is associated with lower public service costs. DiLorenzo (1983) uses two measures of centralization for a sample of 65 of the largest government areas in the United States: (1) percentage of total government spending in a county government area by the four largest jurisdictions and (2) percentage of 'own tax revenue' taken in four largest jurisdictions. $^{5}$ The evidence suggests interjurisdictional competition tends to reduce the cost of providing local public services, and consequently local government expenditures as well.

Schneider's (1986) study of 46 large US metropolitan areas concludes that the number of suburban municipal governments is inversely related to the growth of local governments. Alternative measures of local government growth are based on total expenditures, common expenditures and the number of social services whereas competition is measured as the number of per capita suburban competing governments.

Examining state and local governments, Oates (1985) and Nelson (1986) find no support for the hypothesis that government centralization of spending or taxation policies affects government size. Nelson (1987) finds support of the centralization hypothesis in the case of general-purpose, local governments. Raimondo's (1989) study of state and local governments reports mixed results when government activities are separated into five categories: education, public welfare, hospital, highways and 'others'. Using a panel data set, Wallis and Oates (1988) find a positive and statistically significant relation between state government centralization (state's share of taxes and expenditures) and the size of state and local governments in the United States. Forbes and Zampelli (1989) and Zax (1989) use counties as the unit of observation. Forbes and Zampelli (1989) report no support for the hypothesis that fiscal structure is related to government size whereas Zax (1989) finds evidence in support of the hypothesis.

Relatively few studies include the central government in their examinations of the hypothesis. Some studies exclude

\footnotetext{
${ }^{4}$ Another counterhypothesis is discussed in Anderson and Tollison (1988) which argues that less competition is associated with less total government. One argument is that gains in monopoly power should lower output (assumed equivalent to taxes) and raise prices. While this appears inconsistent with the Brennan and Buchanan hypothesis, this hypothesis appears to model the effects of competition within a jurisdiction rather than between competing jurisdictions.

sJurisdictions are defined at the county level and include municipalities, townships, special districts and county governments.
} 
the central government based on the assumption that taxpayers do not vote-with-their-feet on the basis of central governments. However, because greater centralization may reduce taxpayer-incentives to regulate non-central governments with their mobility, exclusion of the central government ignores this important determinant of the intergovernmental competitive environment for a given size of government. That is, the issue is not whether or not citizens vote-with-their-feet on the basis of central government activity, but whether or not central government activity influences the decisions of taxpayers to regulate non-central governments. ${ }^{6}$ We hypothesize that the larger the central government's share of total government acitivity, the lower are taxpayer-incentives to regulate non-central governments in a Tiebout world. This hypothesis follows from the simple fact that, at the margin, greater centralization implies lower financial incentives to regulate the resulting smaller noncentral governments. The absolute gains from taxpayer mobility may be equally important in that there may exist some threshold level of total tax payments that must be reached before taxpayers find it financially beneficial to regulate government through their mobility.

Another reason why previous studies may exclude central governments from their examinations is based on the assumption that certain activities, like national defence, are not subject to intergovernmental competition. To the extent that national security is identically provided across all states, citizens would not be concerned with voting-with-their-feet in response to monopoly provision; at least, with respect to mobility within one country. However, this argument only applies to those activities which are truly uniform and nonredistributive in nature. Some portion of defence outlays fund military bases, research contracts and jobs in politicians' districts and therefore, to the extent burdens and benefits of taxpayers are not uniform, such activities may affect taxpayer-perception of government performance. In addition, some portion of national defence competes with other central and non-central government activities and may crowd-out redistributive activities of those governments. Therefore, the assumption that all centrally provided goods are pure 'public goods' which have no local aspects seems rather simplifying.

An additional reason suggests the importance of the role of central governments in the determination of total government size. Central governments often guarantee themselves specific portions of taxpayer's income. For example, the US central government is granted monopoly rights in Social Security - a programme that, in 1988 , accounted for $25 \%$ of the tax collections of local, state and federal governments. ${ }^{7}$ If such government monopolies reduce the range of intergovernmental competition, they may lead to larger total government. Moreover, to the extent that a government monopoly behaves like a private monopoly, monopolized programmes may be administered at higher costs than if the government-provider was more concerned about competitors. As discussed below, another way that central governments may affect intergovernmental competition is through a system of intergovernmental grants.

The time series methodologies of Marlow (1988) and Grossman (1989) support Brennan and Buchanan's centralization hypothesis in the case of total government (local, state and federal) in the United States. One possible problem with the time series approach is that it necessitates aggregating local, state and federal spending into single observations for each year. In the United States, for example, this means that spending by the 50 state governments is aggregated into one number in each year. This is potentially a problem when there exist significant differences within each state in such factors as demographics, fiscal structure and fiscal rules (e.g., balanced budget rules or tax limitations).

The cross-country samples of Oates (1972) and Oates (1985) avoid the above aggregation problem. Oates (1972) regressed total government tax revenues as a percentage of national income on measures of centralization and income on a cross-section of 57 countries. Centralization, as measured by the central government's share of tax revenues, exhibited a negative sign, but was not statistically significant. Oates (1985) analysed Spearman rank correlations and regressions on a cross-country sample of 43 countries drawn from the early 1980s. Two subsamples were also considered: 18 industrialized and 25 non-industrialized countries. The former exhibit relatively larger government sectors and considerably less centralization than the latter. For the full sample, Oates (1985) finds highly significant and negative rank correlation between government size and centralization. However, for each subsample, there is not significant rank correlation and Oates (1985) suggests that this is a result of substantial differences between the subsamples. In regressions using population, intergovernmental grants, per capita income and urbanization as control variables, Oates (1985) finds no relationship between government size and centralization

Joulfaian and Marlow (1990) report evidence in support of the centralization hypothesis from examinations of crossstate data on federal, state and local government activities in the United States. Although this study avoids the problems associated with the time series methodologies of Marlow (1988) and Grossman (1989), two important issues remain to be addressed. First, to what extent are empirical results regarding the centralization hypothesis sensitive to the role of the federal government? That is, does the fact that most previous studies exclude the central government a reason for

\footnotetext{
${ }^{6}$ Actually, the fact that there exists immigration may suggest that citizens do vote-with-their-feet on the basis of central government policies as well.

${ }^{7}$ Data obtained from Table no. 429 in the US Department of Commerce, Statistical Abstract of the United States (1988).
} 
why they often find no support for the hypothesis? Because the present study tests the hypothesis on two separate data sets (exclusive and inclusive of the federal government), it is able directly to examine this issue. Second, to what extent do both centralization and fragmentation explain government size? The present study is the first to examine the fragmentation and centralization issues together within a data set that includes all levels of government. As argued in Oates (1989), it is appropriate to distinguish between the roles of the central and non-central governments when examining the hypothesis that fiscal structure influences government size. Our methodology distinguishes between these two separate factors by including them together in the same regression equation. ${ }^{8}$ Evidence from both centralization and fragmentation measures may suggest the relative importance of the central government in the competitive environment between central and non-central governments.

\section{TESTS OF THE DECENTRALIZATION HYPOTHESIS}

We examine two specifications for equations describing total government size. In the first specification, total government size is measured relative to gross state product, a measure of state income, and therefore reflects the government's relative share of the total economy. The second specification measures government size as per capita government expenditure. Both specifications measure government activity in terms of expenditures based on the argument in Marlow (1988) that, when governments run budget deficits, expenditures offer a more complete measure of government size than similar measures utilizing government tax revenues. ${ }^{9}$

The following testing framework is consistent with models in Oates (1985), Marlow (1988), and Joulfaian and Marlow (1990).

GOVI $=\mathrm{f}(P O P, U R B A N, P C Y$, GRANTS, FRAG, DEC)
$G O V 2=\mathrm{f}(P O P, U R B A N, P C Y$, GRANTS, FRAG, DEC $)$

where

$$
\begin{aligned}
\text { GOVI }= & \text { (govt. expenditure)/(gross state product) } \\
\text { GOV2 }= & \text { (govt. expenditure)/population } \\
P O P= & \text { population in } 1000 \mathrm{~s} \\
U R B A N= & \text { percentage of population living within metro } \\
& \text { area } \\
\text { PCY } & \text { per capita income in } 1982 \\
G R A N T S= & \text { (federal grants)/(state and local govt. re- } \\
& \text { venues) } \\
F R A G 1= & \text { (local govt. expenditures)/(state and local } \\
& \text { govt. expenditures) } \\
F R A G 2= & \text { number of local governments } \\
D E C= & \text { (local and state govt. expenditures)/(local, } \\
& \text { state and federal govt. expenditures) }
\end{aligned}
$$

Equations are estimated by ordinary least squares and the unit of observation is the state for three separate years: 1983, 1984 and $1985 .{ }^{10}$ Time periods are based on ease of availability. Due to their relatively large government sectors and centralization, Alaska and Hawaii are excluded. ${ }^{11} \mathrm{~A}$ logistic transformation of $L G O V I=\log ((G O V I /(1-G O V I))$ was considered since GOVI must range from 0 to 1 ; however, the results do not differ from those reported here and therefore are not displayed here.

As discussed above, government size is defined two ways: GOVI and GOV2. GOVI is the ratio of government expenditure over gross state product and GOV2 is the ratio of government expenditure per capita. Federal government expenditures are allocated to each state to include data on salaries and wages, direct payments for individuals and procurement. Not included are net interest on the Federal government debt, international payments, foreign aid and expenditures for various agencies such as the Central Intelligence Agency and the National Security Agency. However, the exclusions are relatively small since, for the years examined in this study, these data reflect approximately $97 \%$ of all federal expenditures (exclusive of net interest payments). ${ }^{12}$

${ }^{8}$ While Joulfaian and Marlow (1990) include a measure of fragmentation in their study, they argue that it is really another measure of centralization. Consequently, they never include separate measures of centralization and fragmentation in the same regression equation. ${ }^{9}$ The argument that government expenditures are better measures than government tax revenues is also consistent with the Ricardian Equivalence theory that hypothesizes that voters properly discount all measures of government finance - taxation and debt issue - when they view government activity.

${ }^{10}$ Data on federal expenditures and grants are obtained from US Department of Commerce 'Federal Expenditures by State' (1983, 1984 and 1985). Data on state and local expenditures, revenues, per capita real income, population and urban population are obtained from various issues of the Statistical Abstract of the United States. Data on gross state product are obtained from US Department of Commerce 'Gross State Product by Industry, 1963-1986' Survey of Current Business 68: 30-46, May 1988.

${ }^{11}$ This is a common practice in previous studies. Inclusion of Hawaii and Alaska results in large increases in statistical significance - both Fscores of the estimating equation and $t$-scores on the $D E C$ coefficient. In addition, Washington, DC is also excluded following the Joulfaian and Marlow (1990) argument that it is an outlier: its government sector and degree of centralization are substantially larger than any of the 50 states.

${ }^{12}$ For fiscal years 1983, 1984 and 1985, these data reflect, respectively, $97 \%$, $98 \%$ and $96 \%$ of total federal expenditures less net interest payments by the federal government. The percentages are calculated from data obtained from the 'Federal Expenditures by State' (1983, 1984 and 1985) and the Economic Report of the President 1990. 
Population $P O P$ and per capita real income $P C Y$ control, respectively, for scale effects and Wagner's Law, or that the demand for government activity is income elastic. Both are expected to exert positive influences on government size. The percentage of population that is urban $U R B A N$ controls for urbanization that may positively affect government size by raising the demand for infrastructure and public services. ${ }^{13}$

The hypothesized signs on GRANTS are positive since, following Logan (1986) and Grossman (1989), grants may positively influence total government size by two means: fostering fiscal illusion and enhancing the taxation powers of the central government. The fiscal illusion argument states that, because grants allow state and local governments to spend without taxing their citizens, the demand for state and local government spending may rise with growing usage of grants. ${ }^{14}$ That is, residents of state and local jurisdictions may be misled into believing that state and local government expenditures are cheaper when they are funded through the central government's grant programme. The other possible effect from grants is their influence on the monopolytaxation powers of the central government. The argument here is that grants allow governments to circumvent, to some degree, the ability of taxpayers to flee 'high-tax' state and local governments. In this sense, grants are viewed as collusive arrangements between governments that serve to raise the monopoly-taxation powers of the central government.

Consistent with the Brennan and Buchanan hypothesis, grant usage is hypothesized to lead to larger total government. No support for the hypothesis that grants affect the size of government is found in Oates (1985), Nelson (1987) and Joulfaian and Marlow (1990). However, Winer (1983), Logan (1986), Schwallie (1989) and Grossman (1989) report evidence in support of the hypothesis that grants affect government size.

$F R A G 1$, the local government's share of total government spending, measures the competitive properties of local and state governments when total government size is defined as the sum of local and state government spending. The Brennan and Buchanan hypothesis predicts that higher levels of $F R A G I$ are expected to be inversely related to government size. FRAGl also measures decentralization when total government size is defined as the sum of state and local governments, i.e., when the federal government is excluded. $F R A G 2$ is an alternative measure which is defined as the number of local governments within each state. This variable is obtained from the Statistical Abstract of the United States (1985) and is only measured every five years. Consequently, its value for 1982 was employed here; note, however, its value does not exhibit wide variation over short periods of time. The Brennan and Buchanan hypothesis predicts that $F R A G 2$ exerts an inverse influence on total government size. Decentralization $D E C$, the share of total government controlled by local and state governments, measures the competitive properties of government when total government size is defined as the sum of local, state and federal government spending. The Brennan and Buchanan hypothesis predicts that $D E C$ will be inversely related to total government size. ${ }^{15}$

To indicate the variation in our sample, Table 1 displays state-by-state values of GOVI, FRAG1 and FRAG2 for 1985. Values of GOVI and FRAGI are displayed for our two definitions of government: with and without the federal sector. For simplicity, other variables are not displayed here. Casual comparison of GOVI between samples with and without the federal sector indicate relatively wide variation in the role that the federal sector plays in each state. The values of $F R A G 1$ and $F R A G 2$ also indicate wide variation in these variables.

\section{Empirical tests}

Table 2 displays regression results based on the expenditures of state and local governments. POP never influences the size of government. $U R B A N$ exerts a statistically significant ( $5 \%$ level) inverse influence on GOV2 in 1983 and 1985; it exerts no influence in equations using GOVI. For all years, $P C Y$ exerts positive and statistically significant influences on GOV2. $P C Y$ is never statistically significant in the cases of GOVI. GRANTS are only found to exert statistically significant negative influences on GOV2 in 1983 and 1985. While all coefficients on FRAGI are negative, as hypothesized by the decentralization hypothesis, they are indifferent from zero. The coefficients on FRAG2 never exert statistically signifiant effects on either GOV1 or GOV2 and are not displayed here. $D E C$ is not included here because it includes the federal government sector in its definition of government structure. The F-scores in Table 2 find that we cannot reject the null hypothesis that all coefficients, in equations using

\footnotetext{
${ }^{13}$ Musgrave and Musgrave (1989, p. 124) make this argument.

${ }^{14}$ Another complication concerns the so-called 'fly-paper' effect which argues that money tends to 'stick' where it is sent. If federal grants to state and local governments foster growth in state and local governments, then grants may also affect the degree of government centralization.

${ }^{15}$ It is noted that a potential problem exists with testing the relationship in this manner. If government expenditures are based, to some extent, on standardization formulae for housing, welfare, health, etc., then 'low-level' governments may receive relatively large expenditures from 'high-level' governments. In this case, the dependent variable may be inversely related to decentralization, but not be consistent with the Brennan and Buchanan model. While this possibility of spurious correlation exists, it potentially affects studies of any aggregation. Following Marlow (1988), both $F R A G$ and $D E C$ are expenditure-based because, when governments-run deficits, revenue-based measures miss a substantial amount of government activity. The federal government has consistently run deficits since 1969.
} 
Table 1. Values of selected variables for 1985

\begin{tabular}{|c|c|c|c|c|c|}
\hline \multirow[b]{2}{*}{ State } & \multicolumn{3}{|c|}{ Without federal sector } & \multicolumn{2}{|c|}{ With federal sector } \\
\hline & $G O V 1$ & $F R A G 1$ & $F R A G 2$ & GOVI & $D E C$ \\
\hline Alabama & 0.12 & 0.30 & 1018 & 0.36 & 0.33 \\
\hline Alaska & 0.20 & 0.07 & 156 & 0.32 & 0.63 \\
\hline Arizona & 0.13 & 0.42 & 452 & 0.33 & 0.38 \\
\hline Arkansas & 0.10 & 0.30 & 1424 & 0.33 & 0.30 \\
\hline California & 0.12 & 0.33 & 4102 & 0.31 & 0.37 \\
\hline Colorado & 0.12 & 0.45 & 1544 & 0.29 & 0.40 \\
\hline Connecticut & 0.09 & 0.35 & 479 & 0.30 & 0.31 \\
\hline Delaware & 0.12 & 0.25 & 217 & 0.28 & 0.44 \\
\hline Florida & 0.12 & 0.45 & 969 & 0.34 & 0.34 \\
\hline Georgia & 0.10 & 0.40 & 1268 & 0.29 & 0.35 \\
\hline Hawaii & 0.12 & 0.20 & 18 & 0.37 & 0.32 \\
\hline Idaho & 0.11 & 0.33 & 1018 & 0.33 & 0.33 \\
\hline Illinois & 0.10 & 0.41 & 6467 & 0.25 & 0.42 \\
\hline Indiana & 0.10 & 0.35 & 2865 & 0.28 & 0.37 \\
\hline Iowa & 0.13 & 0.37 & 1871 & 0.31 & 0.42 \\
\hline Kansas & 0.11 & 0.45 & 3795 & 0.33 & 0.35 \\
\hline Kentucky & 0.10 & 0.26 & 1241 & 0.29 & 0.34 \\
\hline Louisiana & 0.11 & 0.37 & 468 & 0.26 & 0.32 \\
\hline Maine & 0.11 & 0.30 & 806 & 0.36 & 0.31 \\
\hline Maryland & 0.12 & 0.38 & 439 & 0.42 & 0.29 \\
\hline Massachusetts & 0.11 & 0.28 & 798 & 0.32 & 0.33 \\
\hline Michigan & 0.13 & 0.38 & 2643 & 0.29 & 0.46 \\
\hline Minnesota & 0.14 & 0.37 & 3529 & 0.30 & 0.46 \\
\hline Mississippi & 0.11 & 0.31 & 858 & 0.37 & 0.31 \\
\hline Missouri & 0.09 & 0.39 & 3117 & 0.37 & 0.24 \\
\hline Montana & 0.14 & 0.39 & 1029 & 0.38 & 0.36 \\
\hline Nebraska & 0.11 & 0.43 & 3324 & 0.30 & 0.38 \\
\hline Nevada & 0.11 & 0.44 & 184 & 0.28 & 0.39 \\
\hline New Hampshire & 0.08 & 0.44 & 517 & 0.27 & 0.31 \\
\hline New Jersey & 0.11 & 0.37 & 1591 & 0.27 & 0.42 \\
\hline New Mexico & 0.12 & 0.22 & 319 & 0.39 & 0.30 \\
\hline New York & 0.14 & 0.44 & 3249 & 0.31 & 0.46 \\
\hline North Carolina & 0.10 & 0.30 & 905 & 0.26 & 0.38 \\
\hline North Dakota & 0.13 & 0.22 & 2795 & 0.38 & 0.34 \\
\hline Ohio & 0.11 & 0.38 & 3393 & 0.28 & 0.39 \\
\hline Oklahoma & 0.11 & 0.35 & 1702 & 0.29 & 0.38 \\
\hline Oregon & 0.13 & 0.40 & 1454 & 0.32 & 0.42 \\
\hline Pennsylvania & 0.11 & 0.37 & 5198 & 0.31 & 0.35 \\
\hline Rhode Island & 0.14 & 0.27 & 122 & 0.36 & 0.38 \\
\hline South Carolina & 0.11 & 0.26 & 645 & 0.35 & 0.32 \\
\hline South Dakota & 0.12 & 0.38 & 1767 & 0.37 & 0.32 \\
\hline Tennessee & 0.09 & 0.39 & 913 & 0.29 & 0.32 \\
\hline Texas & 0.09 & 0.47 & 4180 & 0.24 & 0.39 \\
\hline Utah & 0.13 & 0.33 & 504 & 0.35 & 0.38 \\
\hline Vermont & 0.12 & 0.26 & 664 & 0.30 & 0.39 \\
\hline Virginia & 0.10 & 0.36 & 407 & 0.38 & 0.26 \\
\hline Washington & 0.13 & 0.33 & 1734 & 0.36 & 0.36 \\
\hline West Virginia & 0.12 & 0.28 & 633 & 0.34 & 0.37 \\
\hline Wisconsin & 0.14 & 0.34 & 2592 & 0.30 & 0.47 \\
\hline Wyoming & 0.13 & 0.36 & 395 & 0.25 & 0.51 \\
\hline Mean & 0.12 & 0.35 & 1636 & 0.32 & 0.37 \\
\hline Standard deviation & 0.02 & 0.08 & 1445 & 0.04 & 0.07 \\
\hline Minimum & 0.08 & 0.07 & 18 & 0.24 & 0.24 \\
\hline Maximum & 0.20 & 0.47 & 6467 & 0.42 & 0.63 \\
\hline
\end{tabular}


Table 2. Fiscal decentralization-government size relation: state and local government expenditures

\begin{tabular}{|c|c|c|c|c|c|c|}
\hline \multirow{2}{*}{$\begin{array}{l}\text { Dependent } \\
\text { variable }\end{array}$} & \multicolumn{2}{|l|}{1983} & \multicolumn{2}{|l|}{1984} & \multicolumn{2}{|l|}{1985} \\
\hline & GOV1 & GOV2 & $G O V 1$ & $G O V 2$ & GOVI & $G O V 2$ \\
\hline \multirow[t]{2}{*}{ Constant } & $0.13^{c}$ & $1.48^{b}$ & $0.12^{c}$ & $1.04^{\mathrm{a}}$ & $0.14^{c}$ & $1.74^{\mathrm{b}}$ \\
\hline & 3.81 & 2.61 & 3.74 & 1.70 & 4.07 & 2.49 \\
\hline \multirow[t]{2}{*}{$P O P$} & $-5 \times 10^{-7}$ & $-2 \times 10^{-6}$ & $-5 \times 10^{-7}$ & $-4 \times 10^{-6}$ & $-2 \times 10^{-7}$ & $-6 \times 10^{-7}$ \\
\hline & 0.90 & 0.20 & 1.02 & 0.39 & 0.45 & 0.01 \\
\hline \multirow[t]{2}{*}{$U R B A N$} & $7 \times 10^{-5}$ & $-0.001^{b}$ & $4 \times 10^{-5}$ & -0.001 & $1 \times 10^{-5}$ & $-0.001^{b}$ \\
\hline & 0.42 & 2.35 & 0.27 & 1.52 & 0.01 & 1.82 \\
\hline \multirow[t]{2}{*}{$P C Y$} & $3 \times 10^{-7}$ & $1 \times 10^{-4}$ & $2 \times 10^{-6}$ & $1 \times 10^{-4 c}$ & $-9 \times 10^{-8}$ & $1 \times 10^{-4 c}$ \\
\hline & 0.16 & 3.95 & 0.94 & 3.89 & 0.01 & 3.23 \\
\hline \multirow[t]{2}{*}{ GRANTS } & -0.01 & $-4.11^{\mathrm{c}}$ & -0.01 & -2.55 & -0.01 & $-3.70^{b}$ \\
\hline & 0.98 & 2.93 & 0.64 & 1.50 & 0.54 & 2.08 \\
\hline \multirow[t]{2}{*}{$F R A G I$} & -0.001 & -0.58 & -0.004 & -0.84 & -0.003 & -0.71 \\
\hline & 0.34 & 0.94 & 1.63 & 1.56 & 0.79 & 0.87 \\
\hline $\mathbf{F}$ & 0.55 & $6.88^{c}$ & 0.85 & $4.96^{c}$ & 0.21 & $4.34^{c}$ \\
\hline$n$ & 48 & 48 & 48 & 48 & 48 & 48 \\
\hline Adj RSQ & -0.05 & 0.38 & -0.02 & 0.30 & -0.09 & 0.26 \\
\hline s.e.e. & 0.0014 & 0.2502 & 0.0014 & 0.2794 & 0.0015 & 0.3155 \\
\hline
\end{tabular}

Absolute value of $t$-statistics below estimated coefficients.

$G O V I=$ (state and local expenditure) $/ G S P$

$G O V 2=$ (state and local expenditure)/population

$P O P=$ population in 1000 s

$U R B A N=$ percentage resident population living within metro area

$P C Y=$ per capita personal income $(\$ 1972)$

$G R A N T S=$ federal grants/state and local revenues

$F R A G 1=$ local expenditures/state and local expenditures

${ }^{\text {a }}$ Significant for a 2 -tailed test at $10 \%$

bignificant for a 2 -tailed test at $5 \%$

'Significant for a 2 -tailed test at $1 \%$

Table 3. Fiscal decentralization-government size relation: state, local and federal government expenditures

\begin{tabular}{|c|c|c|c|c|c|c|}
\hline \multirow{2}{*}{$\begin{array}{l}\text { Dependent } \\
\text { variable }\end{array}$} & \multicolumn{2}{|l|}{1983} & \multicolumn{2}{|l|}{1984} & \multicolumn{2}{|l|}{1985} \\
\hline & GOVI & $G O V 2$ & GOVI & GOV2 & GOVI & $G O V 2$ \\
\hline \multirow[t]{2}{*}{ Constant } & $0.47^{\mathrm{c}}$ & $3.69^{c}$ & $0.42^{\mathrm{c}}$ & $2.96^{\mathrm{b}}$ & $0.42^{\mathrm{c}}$ & $3.68^{\mathrm{b}}$ \\
\hline & 5.56 & 3.06 & 5.08 & 2.09 & 5.06 & 2.44 \\
\hline \multirow[t]{2}{*}{$P O P$} & $-2 \times 10^{-6}$ & $-2 \times 10^{-5}$ & $-2 \times 10^{-6}$ & $-2 \times 10^{-5}$ & $-1 \times 10^{-6}$ & $-2 \times 10^{-5}$ \\
\hline & 1.40 & 1.04 & 1.46 & 1.07 & 1.03 & 0.88 \\
\hline \multirow[t]{2}{*}{$U R B A N$} & $5 \times 10^{-4}$ & -0.001 & $5 \times 10^{-4}$ & $-2 \times 10^{-3}$ & $3 \times 10^{-4}$ & -0.001 \\
\hline & 1.32 & 1.05 & 1.37 & 0.38 & 0.79 & 0.88 \\
\hline \multirow[t]{2}{*}{$P C Y$} & $1 \times 10^{-6}$ & $3 \times 10^{-4 c}$ & $-1 \times 10^{-6}$ & $3 \times 10^{-4 c}$ & $-2 \times 10^{-6}$ & $3 \times 10^{-4 c}$ \\
\hline & 0.24 & 4.49 & 0.24 & 3.98 & 0.38 & 4.03 \\
\hline \multirow[t]{2}{*}{ GRANTS } & 0.01 & -4.00 & 0.16 & -0.62 & 0.22 & -1.86 \\
\hline & 0.33 & 1.42 & 0.80 & 0.18 & 0.12 & 0.52 \\
\hline \multirow[t]{2}{*}{$D E C$} & $-0.49^{c}$ & $-4.20^{\mathrm{c}}$ & $-0.43^{\mathrm{c}}$ & $-3.73^{b}$ & $-0.40^{\mathrm{c}}$ & $-3.66^{b}$ \\
\hline & 5.00 & 3.01 & 4.77 & 2.43 & 4.10 & 2.09 \\
\hline$F$ & $7.66^{\mathrm{c}}$ & $7.61^{c}$ & $7.01^{c}$ & $5.65^{\mathrm{c}}$ & $6.24^{c}$ & $5.21^{\mathrm{c}}$ \\
\hline$n$ & 48 & 48 & 48 & 48 & 48 & 48 \\
\hline Adj RSQ & 0.42 & 0.41 & 0.39 & 0.33 & 0.36 & 0.31 \\
\hline s.e.e. & 0.0035 & 0.4976 & 0.0033 & 0.5612 & 0.0034 & 0.6150 \\
\hline
\end{tabular}

Absolute value of $t$-statistics below estimated coefficients.

$G O V I=$ (state, local and federal expenditure) $/ G S P$

$G O V 2=$ (state, local and federal expenditure)/population

$P O P=$ population in 1000 s

$U R B A N=$ percentage resident population living within metro area

$P C Y=$ per capita personal income (\$1972)

$G R A N T S=$ federal grants/state and local revenues

$D E C=($ state + local expend. $) /($ federal, state + local expend. $)$

asignificant for a 2 -tailed test at $10 \%$

bSignificant for a 2-tailed test at 5\%

'Significant for a 2-tailed test at $1 \%$ 
Table 4. Fiscal decentralization-government size relation: state, local and federal expenditures

\begin{tabular}{|c|c|c|c|c|c|c|}
\hline \multirow{2}{*}{$\begin{array}{l}\text { Dependent } \\
\text { variable }\end{array}$} & \multicolumn{2}{|l|}{1983} & \multicolumn{2}{|l|}{1984} & \multicolumn{2}{|l|}{1985} \\
\hline & GOVI & GOV2 & GOVI & GOV2 & GOVI & GOV2 \\
\hline \multirow[t]{2}{*}{ Constant } & $0.49^{\mathrm{c}}$ & $4.67^{c}$ & $0.45^{c}$ & $3.30^{\mathrm{b}}$ & $0.46^{c}$ & $4.61^{\mathrm{c}}$ \\
\hline & 5.28 & 3.66 & 5.28 & 2.33 & 5.11 & 2.85 \\
\hline \multirow[t]{2}{*}{$P O P$} & $-2 \times 10^{-6}$ & $-1 \times 10^{-5}$ & $-2 \times 10^{-6}$ & $-2 \times 10^{-5}$ & $-1 \times 10^{-6}$ & $-1 \times 10^{-5}$ \\
\hline & 1.27 & 0.74 & 1.54 & 1.14 & 0.90 & 0.72 \\
\hline \multirow[t]{2}{*}{$U R B A N$} & $5 \times 10^{-6}$ & -0.001 & $4 \times 10^{-4}$ & $-3 \times 10^{-3}$ & $3 \times 10^{-4}$ & -0.001 \\
\hline & 1.23 & 1.32 & 1.24 & 0.50 & 0.69 & 1.03 \\
\hline \multirow[t]{2}{*}{$P C Y$} & $-7 \times 10^{-7}$ & $3 \times 10^{-4 c}$ & $1 \times 10^{-6}$ & $3 \times 10^{-4 c}$ & $-8 \times 10^{-7}$ & $3 \times 10^{-4 c}$ \\
\hline & 0.13 & 4.91 & 0.29 & 4.12 & 0.20 & 4.27 \\
\hline \multirow[t]{2}{*}{ GRANTS } & 0.002 & $-5.95^{\mathrm{a}}$ & 0.01 & -1.70 & 0.16 & -3.26 \\
\hline & 0.11 & 2.04 & 0.45 & 0.47 & 0.79 & 0.89 \\
\hline \multirow[t]{2}{*}{$F R A G I$} & -0.005 & $-2.31^{\mathrm{a}}$ & -0.01 & -1.27 & -0.01 & -2.30 \\
\hline & 0.56 & 1.92 & 1.29 & 1.16 & 1.11 & 1.47 \\
\hline \multirow[t]{2}{*}{$D E C$} & $-0.48^{c}$ & $-4.11^{\mathrm{c}}$ & $-0.44^{c}$ & $-4.05^{b}$ & $-0.40^{\mathrm{c}}$ & $-3.66^{b}$ \\
\hline & 4.94 & 3.04 & 4.96 & 2.61 & 4.11 & 2.13 \\
\hline $\mathrm{F}$ & $6.33^{\mathrm{c}}$ & $7.36^{\mathrm{c}}$ & $6.22^{c}$ & $4.97^{\mathrm{c}}$ & $5.43^{\mathrm{c}}$ & $4.83^{c}$ \\
\hline$n$ & 48 & 48 & 48 & 48 & 48 & 48 \\
\hline Adj RSQ & 0.40 & 0.45 & 0.40 & 0.34 & 0.36 & 0.33 \\
\hline s.e.e. & 0.0035 & 0.4824 & 0.0032 & 0.5589 & 0.0034 & 0.6067 \\
\hline
\end{tabular}

Absolute value of $t$-statistics below estimated coefficients.

$G O V I=($ state, local and federal expenditure $) / G S P$

$G O V 2=$ (state, local and federal expenditure)/population

$P O P=$ population in $1000 \mathrm{~s}$

$U R B A N=$ percentage resident population living within metro area

$P C Y=$ per capita personal income $(\$ 1972)$

$G R A N T S=$ federal grants/state and local revenues

$F R A G I=$ local expend $/$ (state + local expend)

$D E C=($ state + local expend. $) /($ federal, state + local expend. $)$

${ }^{\text {a }}$ Significant for a 2 -tailed test at $10 \%$

'Significant for a 2 -tailed test at $5 \%$

'Significant for a 2 -tailed test at $1 \%$

GOV1, are zero. Although we reject the same null hypothesis for equations using $G O V 2$, there remains no statistical relationship between government size and decentralization based on this sample of state and local governments.

Table 3 displays regression results based on the expenditures of local, state and federal governments. FRAGI and $F R A G 2$ are excluded here in order to provide appropriate comparisons with earlier studies of the federal government which only considered DEC. POP, URBAN and GRANTS never influence the size of government. For all years, $P C Y$ exerts positive and statistically significant influences on $G O V 2$. $P C Y$ is never statistically significant in the cases of GOVI. GRANTS are only found to exert statistically significant negative influences on GOV2 in 1983 and 1985. Strong support of the hypothesis that government centralization positively affects the size of government is provided since $D E C$ always exerts a statistically significant inverse effect on both measures of government size.

Table 4 is identical to Table 3 except that it includes FRAGl together with DEC. Results regarding POP,
URBAN and GRANTS remain the same; however, GRANTS now exert an inverse and marginally statistical influence on GOVI in 1983. FRAGl exerts a statistically significant $(10 \%$ level) inverse influence on GOV2 only in 1983. $D E C$ continues to exhibit statistically significant and inverse relationships for all years and both measures of government size.

Table 5 considers the alternative measure of fragmentation, $F R A G 2$, defined as the number of local governments. Similar political competition definitions have been considered in Oates (1985), Forbes and Zampelli (1989), Zax (1989) and Joulfaian and Marlow (1990). The general results regarding $P O P, U R B A N, P C Y, G R A N T S$ and $D E C$ remain the same as before. However, while the coefficient of FRAG1 was statistically significant and negative only in the case of 1983 (with GOV2), the coefficient of FRAG2 is statistically significant and negative in two cases: 1983 and 1984 (with GOV2). Therefore, FRAG2 offers slightly greater support that fragmentation influences government size. 
Table 5. Fiscal decentralization-government size relation: state, local and federal government expenditures

\begin{tabular}{|c|c|c|c|c|c|c|}
\hline \multirow{2}{*}{$\begin{array}{l}\text { Dependent } \\
\text { variable }\end{array}$} & \multicolumn{2}{|l|}{1983} & \multicolumn{2}{|l|}{1984} & \multicolumn{2}{|l|}{1985} \\
\hline & GOVI & GOV2 & GOVI & $G O V 2$ & GOVI & GOV2 \\
\hline Constant & $\begin{array}{l}0.48^{c} \\
5.56\end{array}$ & $\begin{array}{l}3.91^{\mathrm{c}} \\
3.35\end{array}$ & $\begin{array}{l}0.42^{\mathbf{c}} \\
5.10\end{array}$ & $\begin{array}{l}3.06^{b} \\
2.23\end{array}$ & $\begin{array}{l}0.43^{c} \\
5.02\end{array}$ & $\begin{array}{l}3.72^{b} \\
2.49\end{array}$ \\
\hline$P O P$ & $\begin{array}{c}-1 \times 10^{-6} \\
0.68\end{array}$ & $\begin{array}{l}9 \times 10^{-6} \\
0.42\end{array}$ & $\begin{array}{c}-9 \times 10^{-7} \\
0.62\end{array}$ & $\begin{array}{l}6 \times 10^{-6} \\
0.26\end{array}$ & $\begin{array}{c}-9 \times 10^{-7} \\
0.59\end{array}$ & $\begin{array}{c}-4 \times 10^{-6} \\
0.14\end{array}$ \\
\hline$U R B A N$ & $\begin{array}{l}4 \times 10^{-4} \\
1.09\end{array}$ & $\begin{array}{c}-0.001 \\
1.61\end{array}$ & $\begin{array}{l}4 \times 10^{-4} \\
1.08\end{array}$ & $\begin{array}{c}-0.001 \\
0.87\end{array}$ & $\begin{array}{l}3 \times 10^{-4} \\
0.67\end{array}$ & $\begin{array}{c}-0.001 \\
1.21\end{array}$ \\
\hline$P C Y$ & $\begin{array}{c}-9 \times 10^{-7} \\
0.19\end{array}$ & $\begin{array}{l}3 \times 10^{-4} \\
4.81\end{array}$ & $\begin{array}{c}-6 \times 10^{-7} \\
0.15\end{array}$ & $\begin{array}{l}3 \times 10^{-4 c} \\
4.27\end{array}$ & $\begin{array}{c}-1 \times 10^{-6} \\
0.33\end{array}$ & $\begin{array}{l}3 \times 10^{-4 c} \\
4.21\end{array}$ \\
\hline GRANTS & $\begin{array}{l}0.01 \\
0.24\end{array}$ & $\begin{array}{c}-4.73^{\circ} \\
1.73\end{array}$ & $\begin{array}{l}0.14 \\
0.71\end{array}$ & $\begin{array}{r}-1.24 \\
0.36\end{array}$ & $\begin{array}{l}0.22 \\
1.08\end{array}$ & $\begin{array}{r}-2.13 \\
0.60\end{array}$ \\
\hline$F R A G 2$ & $\begin{array}{l}-3 \times 10^{-6} \\
0.66\end{array}$ & $\begin{array}{rl}-1 \times 10^{-4 b} & 2.05\end{array}$ & $\begin{array}{c}-3 \times 10^{-6} \\
0.89\end{array}$ & $\begin{array}{l}-1 \times 10^{-4 a} \\
1.87\end{array}$ & $\begin{array}{l}-2 \times 10^{-6} \\
0.38\end{array}$ & $\begin{array}{l}-1 \times 10^{-4} \\
1.43\end{array}$ \\
\hline$D E C$ & $\begin{array}{c}-0.48^{\mathfrak{c}} \\
4.89\end{array}$ & $\begin{array}{r}-3.95^{c} \\
2.93\end{array}$ & $\begin{array}{c}-0.41^{\mathrm{c}} \\
4.55\end{array}$ & $\begin{array}{c}-3.27^{\mathrm{b}} \\
2.17\end{array}$ & $\begin{array}{c}-0.39^{c} \\
3.97\end{array}$ & $\begin{array}{c}-3.33^{2} \\
1.92\end{array}$ \\
\hline $\mathbf{F}$ & $6.37^{\mathrm{c}}$ & $7.53^{\mathrm{c}}$ & $5.95^{\mathrm{c}}$ & $5.57^{\mathfrak{e}}$ & $5.11^{\mathrm{c}}$ & $4.80^{c}$ \\
\hline$n$ & 48 & 48 & 48 & 48 & 48 & 48 \\
\hline Adj RSQ & 0.41 & 0.45 & 0.39 & 0.37 & 0.34 & 0.33 \\
\hline s.e.e. & 0.0035 & 0.4796 & 0.0033 & 0.5453 & 0.0034 & 0.6074 \\
\hline
\end{tabular}

Absolute value of $t$-statistics below estimated coefficients.

$G O V I=$ (state, local and federal expenditure)/GSP

$G O V 2=($ state, local and federal expenditure $) /$ population

$P O P=$ population in $1000 \mathrm{~s}$

$U R B A N=$ percentage resident population living within metro area

$P C Y=$ per capita personal income (\$1972)

$G R A N T S=$ federal grants/state and local revenues

$F R A G 2$ = number of local governments

$D E C=($ state + local expend. $) /($ federal, state + local expend. $)$

aSignificant for a 2-tailed test at $10 \%$

bignificant for a 2 -tailed test at $5 \%$

'Significant for a 2 -tailed test at $1 \%$

\section{CONCLUSION}

The present work suggests that studies of the relation between fiscal structure and government size that exclude the central government may be based on incomplete measures of intergovernmental competition. The Brennan and Buchanan model is strongly supported by our measure of centralization: the federal government's share of the total government sector. Evidence from two different measures of fragmentation offer weaker support of the Brennan and Buchanan hypothesis. However, differences in support offered by fragmentation and centralization measures of competition appear to mirror the differences stemming from different aggregation schemes. That is, weak support when the central sector is excluded may suggest that the degree of fragmentation, or the degree of competition between local and state governments, is not as important as the share of the central government in the economy.

\section{ACKNOWLEDGEMENT}

The helpful comments of an anonymous referee are gratefully acknowledged.

\section{REFERENCES}

Ahlbrandt, R. (1973) Efficiency in the provision of fire services, Public Choice, 16, 1-15.

Anderson, G. M. and Tollison, R. D. (1988) Legislative monopoly and the size of government, Southern Economic Journal, 54, $529-45$.

Boardman, A. E. and Vining, A. R. (1989) Ownership and performance in competitive environments: a comparison of private, mixed and state-owned enterprises, Journal of Law and Economics, 32, 1-34.

Brennan, G. and Buchanan, J. M. (1980) The Power to Tax: Analytical Foundations of a Fiscal Constitution. Cambridge University Press, Cambridge. 
Council of Economic Advisors (1990) Economic Report of the President, Washington, DC.

DeAllesi, L. (1974) An economic analysis of government ownership and regulation: theory and the evidence from the electric power industry, Public Choice, 19, 1-41.

DiLorenzo, T. J. (1983) Economic competition and political competition: an empirical note, Public Choice, 40, 203-9.

Forbes, K. F. and Zampelli, E. M. (1989) Is Leviathan a mythical beast? American Economic Review, 79, 587-96.

Giertz, J. F. (1981) Centralization and government budget size, Publius, 11, 119-28.

Grewal, B. S. (1988) Locational surplus and its relevance for subnational taxation and intergovernmental grants in a federation, in Taxation and Fiscal Federalism, Brennan, G., Grewal, B. S. and Groenewegen, P. (ed.), Australian National University Press, Sydney.

Grossman, P. J. (1989) Fiscal decentralization and government size: an extension, Public Choice, 62, 63-70.

Joulfaian, D. and Marlow, M. L. (1990) Government size and decentralization: evidence from disaggregated data, Southern Economic Journal, 56, 1094-102.

Logan, R. R. (1986) Fiscal illusion and the grantor government, Journal of Political Economy, 96, 1304-18.

Marlow, M. L. (1988) Fiscal decentralization and government size, Public Choice, 56, 259-69.

Musgrave, R. A. and Musgrave, P. B. (1989) Public Finance in Theory and Practice, 5th edn., McGraw-Hill Book Company, New York.

Nelson, M. A. (1986) An empirical analysis of state and local government tax structures in the context of the Leviathan model of government, Public Choice, 49, 283-94.

Nelson, M. A. (1987) Searching for Leviathan: comment and extension, American Economic Review, 77, 198-204.

Niskanen, W. A. Jr (1971) Bureaucracy and Representative Government, Aldine-Atherton, Chicago.

Oates, W. E. (1972) Fiscal Federalism, Harcourt Brace Jovanovich, New York.

Oates, W. E. (1985) Searching for Leviathan: an empirical study, American Economic Review, 75, 748-57.
Oates, W. E. (1989) Searching for Leviathan: a reply and some further reflections, American Economic Review, 79, 578-83.

Raimondo, H. J. (1989) Leviathan and federalism in the United States, Public Finance Quarterly, 17, $204-15$.

Schneider, M. (1986) Fragmentation and the growth of local government, Public Choice, 48, 255-63.

Schwallie, D. P. (1989) The Impact of Intergovernmental Grants on the Aggregate Public Sector, Quorum Books, Westport, Connecticut.

Tiebout, C. M. (1956) A pure theory of public expenditures, Journal of Political Economy, 64, 416-24.

US Department of Commerce $(1984,1985)$ Bureau of Census, Federal Expenditures by State for Fiscal Year 1983, Washington, D.C.

US Department of Commerce (1988) Gross State Product by Industry, 1963-86, Survey of Current Business, 68, 30-46.

US Department of Commerce, Statistical Abstract of the United States (various years).

Wagner, R. E. and Martin, D. (1978) The institutional framework for municipal incorporation: an economic analysis of local agency formation commissions in California, Journal of Law and Economics, 21, 404-25.

Wagner, R. E. and Weber, W. (1975) Competition, monopoly and the organization of government in metropolitan areas, Journal of Law and Economics, 18, 670-84.

Wallis, J. J. and Oates, W. E. (1988) Does economic sclerosis set in with age? An empirical study of the Olson hypothesis, Kyklos, 41, 397-417.

Winer, S. L. (1983) Some evidence on the effect of separation of spending and tax decisions, Journal of Political Economy, 91 , 126-40.

Wiseman, J. (1990) Principles of political economy: an outline proposal, illustrated by application to fiscal federalism, Constitutional Political Economy, 1, 101-24.

Zax, J. S. (1989) Is there a Leviathan in your neighborhood? American Economic Review, 79, 560-7. 